Findings in Six Patients with Amenorrhoea and Hirsutism

\begin{tabular}{|c|c|c|c|c|c|c|}
\hline $\begin{array}{l}\text { Case } \\
\text { No. }\end{array}$ & Galactorrhoea & $\begin{array}{l}\text { Serum } \\
\text { Prolactin } \\
(\mu \mathrm{g} I)\end{array}$ & $\begin{array}{c}\text { Urinary } \\
\text { 17-Ketosteroid } \\
(\mu \mathrm{mol} / 24 \mathrm{~h})^{*}\end{array}$ & $\begin{array}{c}\text { Urinary } \\
\text { 17-Hydroxycorticoid } \\
(\mu \mathrm{mol} / 24 \mathrm{~h})^{*}\end{array}$ & $\begin{array}{c}\text { Urinary } \\
\text { Pregnanetriol } \\
(\mu \mathrm{mol} / 24 \mathrm{~h})^{*}\end{array}$ & $\begin{array}{c}\text { Plasma } \\
\text { Testosterone } \\
(\mathrm{nmol} / \mathrm{l})^{*}\end{array}$ \\
\hline $\begin{array}{l}1 \\
2 \\
3 \\
4 \\
5 \\
6\end{array}$ & $\begin{array}{l}- \\
- \\
- \\
\overline{+} \\
+ \\
+\end{array}$ & $\begin{array}{r}20 \\
35 \\
45 \\
210 \\
55 \\
240\end{array}$ & $\begin{array}{r}20-45 \\
50 \\
35-48 \\
15-37 \\
23-30 \\
42\end{array}$ & $\begin{array}{r}26-60 \\
40 \\
19-30 \\
25-35 \\
23-32 \\
55\end{array}$ & $\begin{array}{l}0.6 \\
\text { N.D. } \\
0.45 \\
1.2 \\
1.5 \\
1.6\end{array}$ & $\begin{array}{l}2.57 \\
\text { N.D. } \\
1.98 \\
4.58 \\
1.49 \\
2.22\end{array}$ \\
\hline
\end{tabular}
*Normal ranges for healthy women under 40 years: $17-\mathrm{KS} 15-58 \mu \mathrm{mol} / 24 \mathrm{~h} ; 17-\mathrm{OHCS} 21-63 \mu \mathrm{mol} / 24 \mathrm{~h} ;$ pregnanetriol 0.3-5.4 $\mu \mathrm{mol} / 24 \mathrm{~h} ; \mathrm{plasma}$ testosterone $0 \cdot 85-2 \cdot 85 \mathrm{nmol} / 1$.
N.D. = Not done.

Conversion: SI to Truditional Units-17-KS, 17-OHCS, and testosterone: $1 \mu \mathrm{mol} / 1 \approx 0.35 \mathrm{mg}$. Pregnanetriol: $1 \mu \mathrm{mol} / 24 \mathrm{~h} \approx 0.3 \mathrm{mg}$.

We thank the National Pituitary Agency, NIAMDD, Bethesda, Md., for the human prolactin standard and the antiserum; Dr. V. Sternthal, Sandoz, Basle, for bromocriptine; and Miss Sirkka Soikkeli and Mrs. Virpi Tiilikainen for technical assistance. Our study was supported by grants from the Association of the Finnish Life Insurance Companies and the Sigrid Jusélius Foundation.

1 Besser, G. M., et al., British Medical fournal, 1972, 3, 669.

2 Friesen, H., and Hwang, P., Annual Review of Medicine, 1973, 24, 251.

3 Forbes, A. P., et al., fournal of Clinical Endocrinology and Metabolism, 1954, 14, 265.

4 Hafiez, A. A., et al., fournal of Endocrinology, 1972, 52, 327.

5 Boyns, A. R., et al., in Prolactin and Carcinogenesis, ed. A. R. Boyns and K. Griffiths, p. 207. Cardiff, Alpha Omega Alpha, 1972.

University Central Hospital, University of Helsinki, Helsinki, Finland

M. SEPPÄLÄ, M.D., Senior Lecturer

E. HIRVONEN, M.D., Consultant

\section{Folic acid deficiency during intensive therapy}

Folic acid is essential for normal haemopoiesis and in its absence megaloblastic maturation occurs. During intensive therapy, red cell changes are often obscured by transfusion and neutrophil hypersegmentation may be attributed to renal failure.' Severe thrombocytopenia may develop because of "megaloblastic" megakaryocyte maturation and this should respond to folic acid treatment. We report two cases which illustrate these points and draw attention to the rapidity of onset of the megaloblastic change.

\section{Case reports}

Case 1.-A fit 28-year-old man sustained an extensive crush injury to the lower limbs and developed acute renal failure requiring peritoneal dialysis. Haematology on admission was haemoglobin $14.6 \mathrm{~g} / \mathrm{dl}$, mean cell volume (M.C.V.) $86 \mathrm{fl}$, and platelet count $175 \cdot 10^{9} / \mathrm{l}$. After 17 days the haemoglobin was $7.4 \mathrm{~g} / \mathrm{dl}$, M.C.V. $90 \mathrm{fl}$, and platelet count $60 \times 10^{9} / 1$. The bone marrow was markedly megaloblastic. Microbiological estimation of serum vitamin $\mathrm{B}_{12}$ and folic acid was attempted but was inhibited by antibiotics. Folic acid $15 \mathrm{mg}$ intravenously daily was begun. Haematological follow-up showed no change in M.C.V. and no reticulocytosis. The response of the platelet count is shown in the figure. A repeat bone marrow at nine days was normoblastic.

Case 2.-A well-nourished 62-year-old man had an aortic aneurysm repaired with a Dacron prosthesis. Preoperatively his haemoglobin was $13.5 \mathrm{~g} / \mathrm{dl}$, M.C.V. $82 \mathrm{fl}$, platelet count $240 \cdot 10^{9} / 1$ and postoperatively, respectively, $10.5 \mathrm{~g} / \mathrm{dl}, 86 \mathrm{fl}, 67 \times 10^{9} / 1$ after an 18 pint $(10.22 \mathrm{l})$ blood transfusion. The patient developed acute renal failure requiring haemodialysis. Seven days later the haemoglobin was $11.9 \mathrm{~g} / \mathrm{dl}$, M.C.V. $86 \mathrm{fl}$, platelet count 30. $10^{9} / 1$, and the peripheral film showed hypersegmented neutrophils. The bone marrow was megaloblastic. Estimation of serum folic acid was inhibited by antibiotics but the vitamin $\mathrm{B}_{12}$ concentration was $500 \mathrm{ng} / \mathrm{l}$. Folic acid $15 \mathrm{mg}$ intravenously daily was started. Follow up haematological data showed no change in M.C.V., an increase in reticulocytes of $5 \%$ at 10 days, and a recovery of the platelet count at eight days to $170 \times 10^{9} / 1$ and at ten days to $300 \times 10^{9} / 1$. Bone marrow examination after eight days showed normoblastic erythropoiesis.

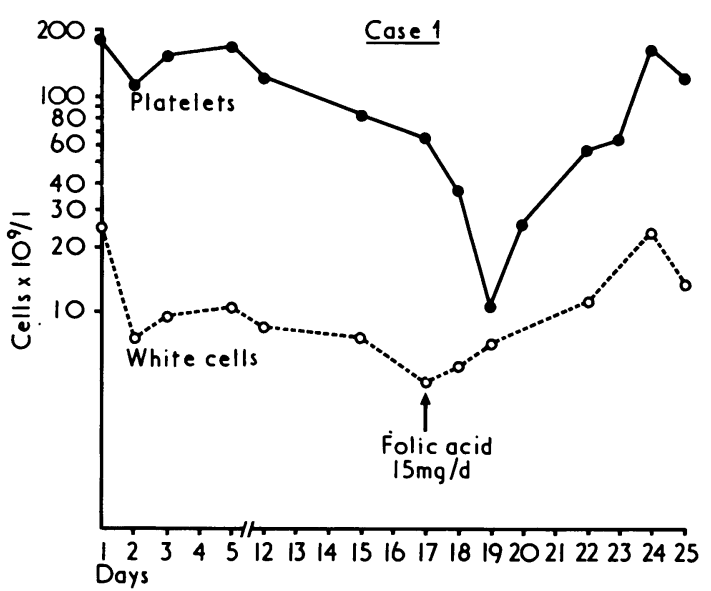

Platelet and white cell counts in case 1 showing response to folic acid.

\section{Discussion}

The two cases show the occurrence of rapidly developing megaloblastosis and thrombocytopenia which respond to folic acid treatment. Vitamin $B_{12}$ radioimmunoassay was not available at that time and the possibility of vitamin $B_{12}$ deficiency in case 1 was considered extremely remote. The interval from admission to diagnosis was 17 days in case 1 and eight days in case 2 , but Herbert $^{2}$ estimated that folic acid stores in the body can sustain normal erythropoiesis for 19 weeks. These patients developed megaloblastosis in less than three weeks suggesting that in the severely traumatized patient folic acid stores are either rapidly depleted or their metabolism is inhibited.

Infection affects folate metabolism, possibly by increasing folate requirements, ${ }^{3}$ and it has also been claimed that a factor develops during infection which antagonizes normal folic acid utilization. ${ }^{4}$ Haemodialysis in the management of renal failure depresses folic acid levels and folic acid is dialysable whereas vitamin $B_{12}$ is not.' Both our patients had infections and were being dialysed. In each case severe tissue trauma had occurred. Folic acid requirements increase in myelofibrosis, ${ }^{5}$ in which increased turnover of the expanded myeloid pool increases folate utilization. Massive tissue trauma may increase tissue demand in a similar way.

Our experience suggests that it is unwise to rely on the folic acid store of severely traumatized patients even for short periods. Normal vitamin $\mathrm{B}_{12}$ stores should last for three years but a subclinical vitamin $B_{12}$ deficiency should be excluded when folic acid supplements are used in view of the risk of precipitating a neuropathy.

1 Hampers, C. L., et al., New England fournal of Medicine, 1967, 276, 551. 2 Herbert, V., Transactions of Association of American Physicians, 1962, 75, 307.

${ }^{3}$ Roberts, P. D., Hoffbrand, A. V., and Mollin, D. L., British Medical fournal, 1966, 2, 198.

4 Chanarin, I., and Davey, D. A., British fournal of Haematology, 1964, 10, 314.

${ }^{5}$ Hoffbrand, A. V., et al., Quarterly fournal of Medicine, 1968, 37, 493.

\section{The London Hospital, London E1 1 BB}

R. M. IBBOTSON, M.R.C.P., M.R.C.PATH., Senior Registrar, Department of Haematology

B. T. COLVIN, M.B., M.R.C.P., Registrar, Department of Haematology M. P. COLVIN, M.B., F.F.A.R.C.S., Senior Lecturer, Anaesthetics Unit 